DOI: $10.21802 /$ artm.2020.1.13.70.

УДК 6616-083+616.366-002+616-036.22

\title{
ХАРАКТЕРИСТИКА ПАЦІЕНТІВ ІЗ ГОСТРИМ КАЛЬКУЛЬОЗНИМ ХОЛЕЦИСТИТОМ НА СТАЦІОНАРНОМУ ЕТАПІ РЕАБІЛІТАЦІї
}

\author{
Н.Р. Голод
}

Івано-Франківський національний медичний університет, кафедра фізичної реабілітації, ерготерапї з курсом фізичного виховання, м. Івано-Франківськ, Украйна,

ORCID ID: 0000-0003-0996-6920, e-mail: n.golod@ukr.net

Резюме. Мета дослідження: провести характеристику пацієнтів із гострим калькульозним холециститом на стаціонарному етапі реабілітації.

Методи дослідження: синтез та аналіз фахових наукових джерел; ретроспективний аналіз 50 історій хворіб пацієнтів із гострим калькульозним холециститом (ГКХ), які знаходилися на стаціонарному лікуванні у хірургічному відділенні Івано-Франківської центральної міської клінічної лікарні у 2018 році.

Висновки. Найбільше пацієнтів (38\%) із ГКХ - це представники середнього віку (44-60 років). Найбільша кількість ускладнень ГКХ - це ускладнення місцевим необмеженим серозним перитонітом (18\%).

У ранньому післяопераційному періоді у пацієнтів виникли такі ускладнення: гострий панкреатит - 4 випадки, загострення хронічного панкреатиту - 16 , загострення хронічного бронхіту - 5 , післяопераційна пневмонія - 3, кровотеча 3 контрапертури - 1, жовчетеча - 7, тромбофлебіт нижніх кінцівок - 2, тромбоз нижніх кінцівок (суральні вени) - 2, загострення виразкової хвороби дванадцятипалої кишки - 5 .

У 86\% пацієнтів були наявні супутні хронічні неінфекційні захворювання. Найбільша кількість пацієнтів була із ожирінням різного ступеня $-36 \%$; на другому місці по поширеності - це пацієнти із хронічним панкреатитом - 24\%; на третьому - із IXC та ГХ другої ступені по 20\% пацієнтів; на четвертому місці за чисельністю - це пацієнти із гіпертонічною хворобою I ступеню; виразковою хворобою дванадцятипалої кишки п'ятому $-12 \%$; $з$ цукровим діабетом другого типу на шостому - $10 \%$; на сьомому - пацієнти із серцевою недостатністю $(\mathrm{CH})$ першого ступеню - 8\%; на восьмому - пацієнти із ХОЗЛ - 7\%. Найдовше перебували у відділення пацієнти із гострим гангренозним калькульозним холециститом (ГГКХ).

Проведений аналіз допоможе обгрунтувати створення та проведення алгоритму реабілітаційних заходів.

Ключові слова: гострий калькульозний холецистит, реабілітація, характеристика пацієнтів.

Вступ. В Україні захворюваність на жовчекам'яну (ЖКХ) складає $10 \%$ населення [1]. У США ЖКХ діагностують у $14-18 \%$ населення, причому в $80 \%$ випадків із безсимптомним перебігом. 3 кожним роком захворюваність збільшується на 1 млн випадків, що $\epsilon$ приводом до щорічного виконання 700 тис. холецистектомій (XE) з витратами на лікування та реабілітацію понад 10 млрд доларів США [5]. Частота захворюваності серед жінок у 2-3 рази вища відносно чоловіків. Це пов'язують із впливом естрогенів на літогенні процеси, зниженням скорочувальної функції жовчного міхура, що спостерігається, зокрема, в клімактеричному періоді у жінок, в той час, як у чоловіків гормональні зміни не впливають на утворення каменів [1]. Ризик розвитку ЖКХ збільшується у вагітних, особливо при повторних вагітностях, коли утворення конкрементів в жовчному міхурі відмічають у 5-12 \% жінок [1]

Глобальне поширення ЖКХ поєднується 3 ішемічною хворобою серця (IXC), ожирінням, гіпертонічною хворобою (ГХ) та цукровим діабетом (ЦД), які $є$ взаємно обтяжливими та впливають на перебіг та розвиток ускладнень окремих патологій, формуючи коморбідний комплекс метаболічного синдрому [4]. Симптомні ускладнення виникають приблизно у $12-25 \%$ хворих ЖКХ, в тому числі у $65-70 \%$ пацієнтів похилого і старечого віку, що призводить до госпіталізації та значних затрат на лікування $[2,3]$.

Збільшення кількості пацієнтів з ЖКХ зумовлене впливом модифікованих факторів ризику, зокрема особливостями харчування з дефіцитом клітковини у раціоні та харчовими надмірностями, особливо споживанням «швидких» вуглеводів, високим рівнем ожиріння, малорухливим способом життя, наявністю супутніх метаболічних захворювань [6].

Лапароскопічне лікування жовчнокам'яної хвороби протягом багатьох років зберігає свою безперечну актуальність, на сьогодні це втручання називають «золотим стандартом» у лікуванні цього захворювання. Перевагою малоінвазивних операцій $є$ скорочення часу перебування хворого в стаціонарі i зменшення термінів тимчасової непрацездатності.

Наявні ускладнення ГКХ та супутні захворювання безперечно призводять до важчого перебігу раннього та пізнього післяопераційного періодів, вимагають диференційованого підходу до реабілітаційних заходів.

Результати досліджень та їх обговорення. Проведено ретроспективний аналіз 50 історій хворіб пацієнтів із ГКХ, які знаходилися на стаціонарному лікуванні у хірургічному відділенні ІваноФранківської центральної міської клінічної лікарні у 
2018 році. Середній вік пацієнтів загалом склав $57,32 \pm 2,03$ років. Розподіл пацієнтів за віком і статтю у відсотках і за абсолютною кількістю подано у таблиці 1. Із проаналізованих медичних карт пацієнтів чоловіків було $36 \%$, а жінок $64 \%$. Найбільший відсоток пацієнтів був серед представників середнього віку (44-60 років) - 38\%; на другому місці за чисельністю представники похилого віку (60-75 років) - 34\%; на третьому - пацієнти молодого віку
(25-44 років) - 16\%; і найменше за чисельністю було пацієнтів старечого віку (75-90 років).

Структура основних діагнозів була такою: гострий калькульозний холецистит (ГКХ) - 24\%, гострий флегмонозний калькульозний холецистит ГФКХ - 40\%; гострий гангренозний калькульозний холецистит (ГГКХ) - 36\% (рис.1).

Структура ускладнень основного діагнозу, які виникли у пацієнтів із ГКХ подана на рисунку 2.

Таблиця 1

\begin{tabular}{|l|c|c|c|c|}
\hline & $\begin{array}{c}25-44 \\
\text { молодий } \\
\text { вік }\end{array}$ & $\begin{array}{c}44-60 \\
\text { середній вік }\end{array}$ & $\begin{array}{c}60-75 \\
\text { похилий вік }\end{array}$ & $\begin{array}{c}75-90 \\
\text { старечий вік }\end{array}$ \\
\hline Чоловіки (абсолютна кількість) & 4 & 7 & 4 & 3 \\
\hline Чоловіки (\%) & 8 & 14 & 8 & 6 \\
\hline Жінки (абсолютна кількість) & 4 & 12 & 13 & 3 \\
\hline Жінки (\%) & 8 & 24 & 26 & 6 \\
\hline Всього (абсолютна кількість) & 8 & 19 & 17 & 12 \\
\hline Всього (\%) & 16 & 38 & 34 & \\
\hline
\end{tabular}

(\%)

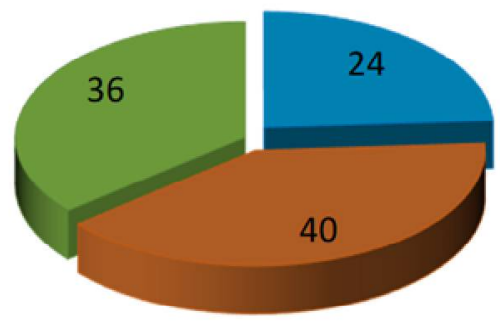

(\%)

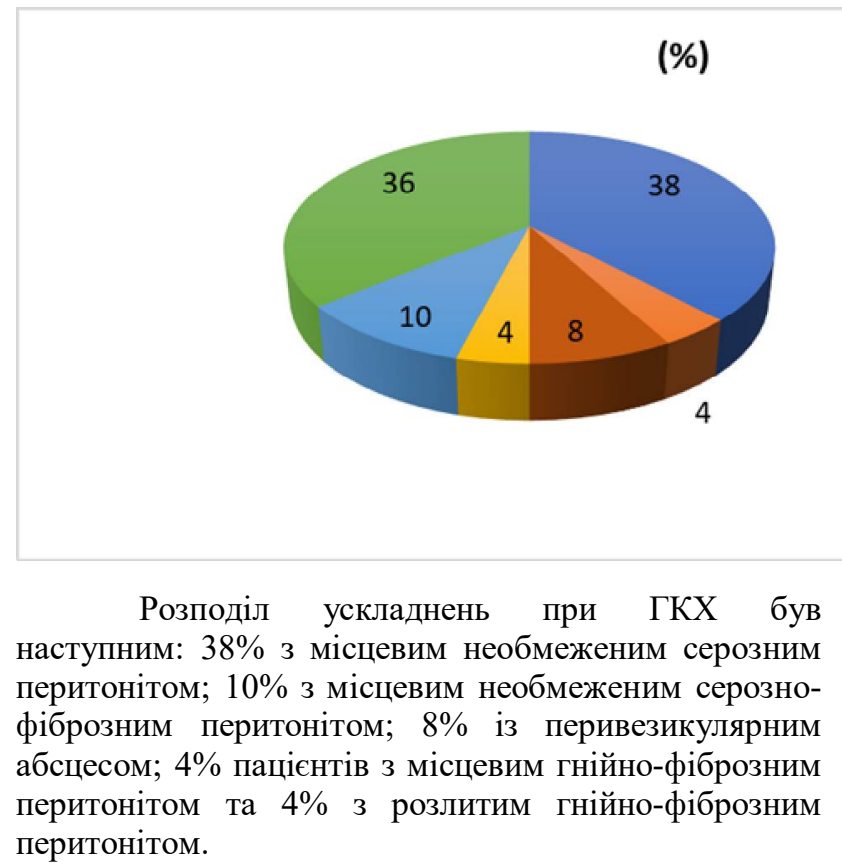

Гострий калькульозний холецистит

Гострий флегмонозний калькульозний холецестит

Гострий гангренозний калькульозний холецистит
Рис. 1. Структура основних діагнозів ГКХ
Рис. 2. Структура ускладнень основного діагнозу загалом

— Місцевий гнійно-фіброзний перитоніт

口 Місцевий необмежений серозно-фіброзний перитоніт

п Неускладнений

Також у ранньому післяопераційному періоді у пацієнтів виникли такі ускладнення: гострий панкреатит - 4 випадки, загострення хронічного панкреатиту - 16, загострення хронічного бронхіту 5, післяопераційна пневмонія - 3, кровотеча 3 контрапертури - 1, жовчетеча - 7, тромбофлебіт нижніх кінцівок - 2, тромбоз нижніх кінцівок 
(суральні вени) - 2, загострення виразкової хвороби дванадцятипалої кишки - 5.

Згідно результатів дослідження встановлено, що тривалість госпіталізації в середньому склала $6,70 \pm 0,39$ дні. Найдовше перебували у відділенні пацієнти із ГГКХ 7,78 $\pm 0,85$ дні, а найменше із ГКХ $5,50 \pm 0,36$. Середній термін періоду до госпіталізації після початку перших ознак ГКХ становив 61,48 $\pm 6,68$ год. Більш детально показники подано у таблиці 2.

Таблиця 2

Тривалість перебування у відділенні

\begin{tabular}{|l|c|c|c|}
\hline & $\begin{array}{c}\text { Середнє } \\
\text { значення } \\
(\text { дні) } \\
(\mathrm{M} \pm \mathrm{m})\end{array}$ & $\begin{array}{c}\text { Максимальна } \\
\text { тривалість } \\
\text { перебування } \\
\text { у відділенні } \\
\text { (дні) }\end{array}$ & $\begin{array}{c}\text { Мінімальна } \\
\text { тривалість } \\
\text { перебування у } \\
\text { відділенні (дні) }\end{array}$ \\
\hline ГФКХ & $6,45 \pm 0,46$ & 13 & 4 \\
\hline ГКХ & $7,78 \pm 0,85$ & 17 & 4 \\
\hline ГКХ & $5,50 \pm 0,36$ & 8 & 4 \\
\hline
\end{tabular}

Аналізуючи наявність супутніх захворювань, ми встановили, що супутніх захворювань не було тільки у 16\% пацієнтів з ГКХ; середній вік пацієнтів без супутніх захворювань склав $53,75 \pm 1,72$ років. Всі інші мали супутні захворювання, які можна віднести до хронічних неінфекційних захворювань. Структура супутніх діагнозів пацієнтів із ГКХ подана на рисунку 3.

Найбільша кість пацієнтів була із ожирінням різного ступеня - це $36 \%$; на другому місці по поширеності - це пацієнти із хронічним панкреатитом - 24\%; на третьому - iз IXC та ГX другої ступені по 20\% паціснтів; на четвертому місці за чисельністю - це пацієнти із гіпертонічною хворобою I ступеню; виразковою хворобою дванадцятипалої кишки - п'ятому $-12 \%$; 3 цукровим діабетом другого типу на шостому - $10 \%$; на сьомому - пацієнти із серцевою недостатністю $(\mathrm{CH})$ першого ступеню - 8\%; на восьмому - пацієнти із ХОЗЛ - 7\%.

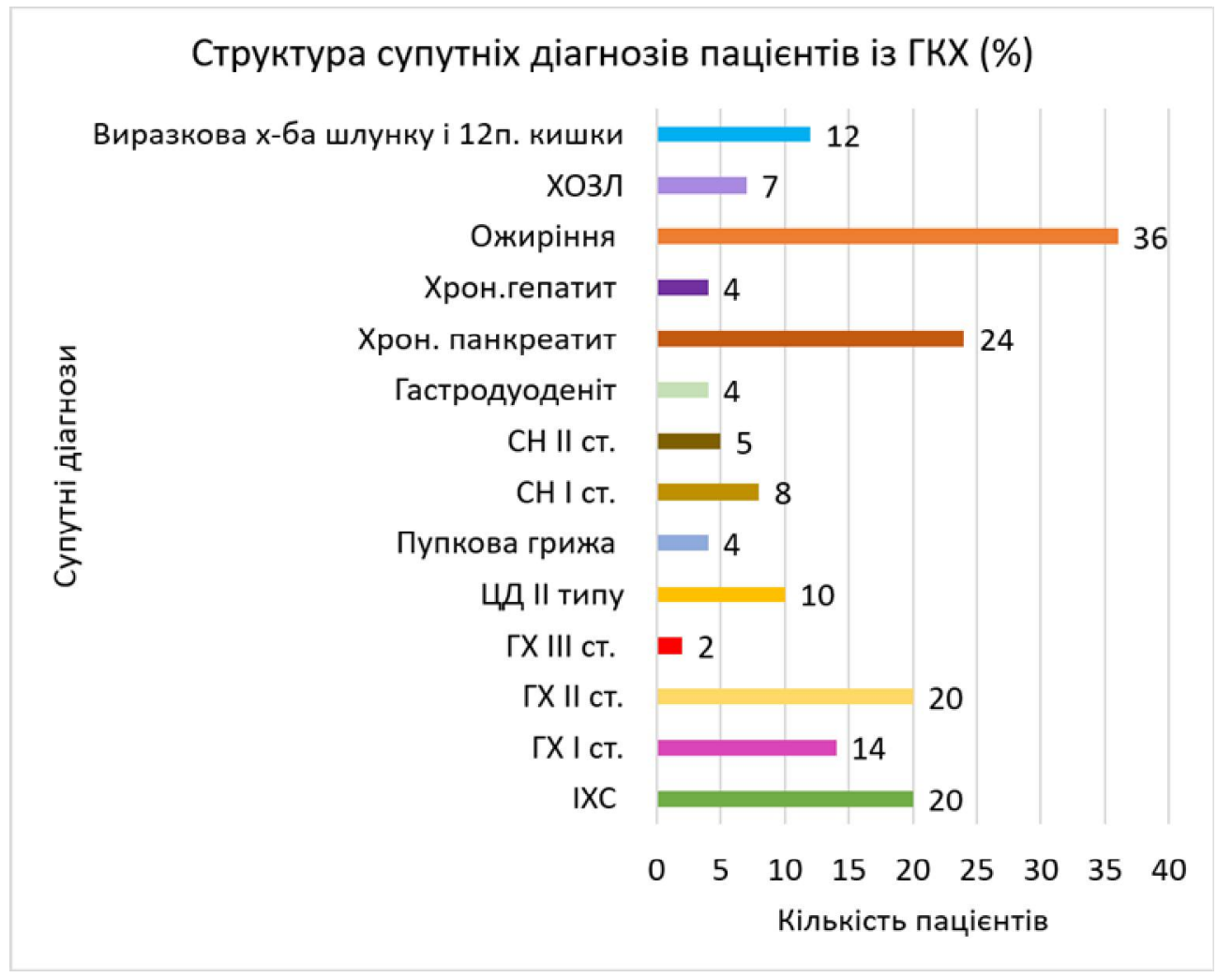

Рис. 3. Структура супутніх діагнозів пацієнтів із ГКХ

У багатьох пацієнтів зустрічається декілька супутніх патологій, це, як правило, пацієнти із різними ступенями ожиріння, чим вища ступінь, тим більше супутніх діагнозів. Представники обох статей схильні до серцево-судинних захворювань, захворювань шлунково-кишкового тракту, але спостерігається більша кількість жінок із ожирінням i цукровим діабетом II типу. Більшість чоловіків хворіють на ХОЗЛ, це очевидно, обумовлено наявністю шкідливої звички - куріння.

Наше дослідження підтверджує результати попередніх дослідників про наявність у пацієнтів із
ГКХ супутніх захворювань, які можна віднести до хронічних неінфекційних захворювань, проте, у порівнянні із попередніми дослідженнями вказаних у посиланнях авторів спостерігається тенденція до виникнення даної патології у представників більш молодшого віку.

\section{Висновки:}

1. В Україні захворюваність на жовчекам'яну (ЖКХ) складає 10 \% населення. Згідно аналізу вікової структури пацієнтів встановлено, що спостерігається тенденція до захворюваності на ГКХ людей більш молодшого віку, у порівнянні із попередніми роками. 
Найбільше пацієнтів із ГКХ - це представники середнього віку (44-60 років).

2. Найбільша кількість ускладнень ГКХ - це ускладнення місцевим необмеженим серозним перитонітом (18\%). Також у ранньому післяопераційному періоді найбільше було випадів загострення хронічного панкреатиту та бронхіту. У $86 \%$ пацієнтів були супутні хронічні неінфекційні захворювання, найбільше було пацієнтів із ожирінням різного ступеню - 36\%.

3. Встановлено, що найдовше перебували у хірургічному відділенні пацієнти із ГГКХ.

4. У багатьох пацієнтів зустрічається декілька супутніх патологій, це як правило, пацієнти із різними ступенями ожиріння, чим вища ступінь, тим більше супутніх діагнозів. Представники обох статей схильні до серцево-судинних захворювань, захворювань шлунково-кишкового тракту, але спостерігається більша кількість жінок із ожирінням і цукровим діабетом II типу. Більшість чоловіків хворіють на ХОЗЛ, це очевидно, обумовлено наявністю шкідливої звички - куріння.

5. Проведений аналіз дає можливість обгрунтувати створення та проведення алгоритму реабілітаційних заходів, які повинні починатися під час операції, продовжуватися в ранньому післяопераційному періоді та після виписки із стаціонару.

\section{References:}

1. Vakhrushev YAM, Khokhlacheva NA. Zhelchnokamennaya bolezn: épydemyolohyya, faktory ryska, osobennosty klynycheskoho techenyya, profylaktyka. Arkhyv vnutrenney medytsyny. 2016; 3(29):30-35.

2. Kanikovskyy OYE, Vorovskyy OO, Karyy YAV, ta in. Sposoby pokrashchennya rezultativ laparoskopichnoyi kholetsystektomiyi u khvorykh $\mathrm{z}$ uskladnenym perebihom hostroho ta khronichnoho kalkuloznoho kholetsystytu. Kharkivska khirurhichna shkola. 2016; 2(77):48-51.

3. Nychytaylo MYU, Kanikoskyy OYE, Karyy YAV, ta in. Khirurhichna taktyka za uskladnenykh form zhovchokam yanoyi khvoroby u patsiyentiv povazhnoho viku. Klinichna khirurhiya. 2017; 5:9-12.

4. Saito R, Abe T, Hanada K, et al. Impact of comorbidities on the postoperative outcomes of acute cholecystitis following early cholecystectomy. Surg. Today. 2017; 47:1-8.

5. Stinton LM, Shaffer EA. Epidemiology of Gallbladder Disease: Cholelithiasis and Cancer. Gut. Liver. 2012; 6:172-187.

6. Kushnir IE. Naslidky kholetsystektomii ta pryntsypy yikh korektsii y profilaktyky Tematychnyi nomer «Hastroenterolohiia. Hepatolohiia. Koloproktolohiia». 2019; 2 (52):40-42. http:// health-ua. com/article/4278 2-nasldki-holetcistektom-taprintcipi-h-korektcjproflaktiki.
УДК 6616-083 + 616.366-002 + 616-036.22

\section{ХАРАКТЕРИСТИКА ПАЦИЕНТОВ С ОСТРЫМ КАЛЬКУЛЕЗНЫМ ХОЛЕЦИСТИТОМ НА СТАЦИОНАРНОМ ЭТАПЕ РЕАБИЛИТАЦИИ}

\section{Н.Р. Голод}

Ивано-Франковский нацииональный медиичнский университет, кафедра физической реабилитации, эрготерапии с курсом физического воспитания,

2. Ивано-Франковск, Украина,

ORCID ID: 0000-0003-0996-6920,

e-mail:n.golod@ukr.net

Резюме. Цель исследования: провести характеристику пациентов с острым калькулезным холециститом на стационарном этапе реабилитации.

Методы исследования: провести характеристику пациентов с острым калькулезным холециститом на стационарном этапе реабилитации.

Методы исследования: синтез и анализ профессиональных научных источников; ретроспективный анализ 50 историй болезней пациентов с острым калькулезным холециститом (ГКХ), которые находились на стационарном лечении в хирургическом отделении Ивано-Франковской центральной городской клинической больницы в 2018 году.

Выводы. Больше всего пациентов (38\%) с ГКХ - это представители среднего возраста (44-60 лет). Наибольшее количество осложнений ГКХ - это осложнение местным неограниченным серозным перитонитом (18\%).

В раннем послеоперационном периоде у пациентов возникли следующие осложнения: острый панкреатит - 4 случая, обострение хронического панкреатита - 16, обострение хронического бронхита - 5, послеоперационная пневмония - 3 , кровотечение из контрапертуры - 1, жолчное течение - 7, тромбофлебит нижних конечностей - 2, тромбоз нижних конечностей (суральные вены) - 2, обострение язвенной болезни двенадцатиперстной кишки - 5.

У $86 \%$ пациентов имелись сопутствующие хронические неинфекционные заболевания. Наибольшее число пациентов было с ожирением различной степени $-36 \%$; на втором месте по распространенности - это пациенты с хроническим панкреатитом - 24\%; на третьем - с ИБС и ГБ второй степени по 20\% пациентов; на четвертом месте по численности - это пациенты с гипертонической болезнью I степени; язвенной болезнью двенадцатиперстной кишки - пятом - 12\%; с сахарным диабетом второго типа на шестом - $10 \%$; на седьмом - пациенты с сердечной недостаточностью $(\mathrm{CH})$ первой степени - 8\%; на восьмом - пациенты с ХОБЛ - 7\%. Дольше находились в отделение пациенты с острым гангренозным калькулезным холециститом (ГГКХ).

Проведенный анализ поможет обосновать создание и проведение алгоритма реабилитационных мероприятий.

Ключевые слова: острый калькулезный холецистит, реабилитация, характеристика пациентов. 
UDC 6616-083 + 616.366-002 + 616-036.22

CHARACTERISTICS OF PATIENTS WITH ACUTE CALCULOUS CHOLECYSTITIS AT THE INPATIENT PHASE OF REHABILITATION

\author{
N.R. Golod \\ Ivano-Frankivsk National Medical University, \\ Department of Physical Rehabilitation, Ergotherapy with \\ a Course of Physical Welfare, Ivano-Frankivsk, Ukraine, \\ ORCID ID: 0000-0003-0996-6920, \\ e-mail:n.golod@ukr.net
}

Abstract. Purpose of the study: to characterize patients with acute calculous cholecystitis at the inpatient phase of rehabilitation.

Research methods: synthesis and analysis of professional scientific sources; retrospective analysis of 50 medical records of ACC patients undergoing inpatient treatment at the surgery department of the IvanoFrankivsk Central City Clinical Hospital in 2018.

Conclusions. In Ukraine, the incidence of cholelithiasis is $10 \%$ of the population. According to the analysis of patients' age structure, it is established that there is a tendency for the incidence of ACC for people of younger age, compared with previous years. Most patients with acute calculous cholecystitis (ACC) are middle-aged (44-60 years) - 38\%. The average age of the patients was $57.32 \pm 2.03$ years.

The structure of the main diagnoses was as follows: (ACC) - 24\%, acute phlegmonous calculous cholecystitis AFCC - 40\%; acute gangrenous calculous cholecystitis (AGCC) - 36\%.

The distribution of complications in ACC was as follows: $38 \%$ with local unrestricted serous peritonitis; $10 \%$ with local unrestricted serous-fibrous peritonitis; $8 \%$ with perivezicular abscess; $4 \%$ of patients with local purulent-fibrous peritonitis and $4 \%$ of patients with diffuse purulent-fibrous peritonitis.

In the early postoperative period, the patients had the following complications: acute pancreatitis - 4 cases, exacerbation of chronic pancreatitis - 16, exacerbation of chronic bronchitis - 5, postoperative pneumonia -
3, bleeding from contrapertory - 1, thrombophobia - 7 , thrombophobia thrombosis of the lower extremities (sural veins) - 2, exacerbation of peptic ulcer of the duodenum 5.

According to the results of the study, it was found that the length of hospitalization averaged $6.70 \pm$ 0.39 days. Patients with AGCC were $7.78 \pm 0.85$ days longest in the department and $5.50 \pm 0.36$ days with ACC. The average time to hospitalization after the onset of the first signs of ACC was $61.48 \pm 6.68 \mathrm{~h}$. It should be noted that the longer time has passed since the first symptoms of ACC appeared, the more difficult the complications of the basic diagnosis. Patients with AGCC were the longest in the department.

The largest bone mass of patients was of varying degrees of obesity - $36 \%$; the second most prevalent is patients with chronic pancreatitis - $24 \%$; on the third $20 \%$ of patients with coronary heart disease and acute cholestasis of the second stage; in fourth place in number - are patients with grade I hypertension; peptic ulcer of the duodenum - fifth - $12 \%$; with diabetes of the second type on the sixth - $10 \%$; on the seventh - patients with first-degree heart failure (HF) - $8 \%$; on the eighth - patients with $\mathrm{COPD}$ (chronic obstructive pulmonary disease )- $7 \%$.

Many patients have several concomitant pathologies, usually patients with different degrees of obesity, the higher the degree, the more concomitant diagnoses. Representatives of both sexes are prone to cardiovascular diseases, diseases of the gastrointestinal tract, but there are more women with obesity and type II diabetes. Most men suffer from chronic obstructive pulmonary disease, which is obviously due to the presence of a bad smoking habit.

The analysis made it possible to substantiate the creation and implementation of the algorithm of rehabilitation measures, which should begin during surgery, continue in the early postoperative period and after discharge from the hospital.

Keywords: acute calculous cholecystitis, rehabilitation, patient characteristics. 